\title{
HIVCore operations research workshop summary report
}

Nrupa Jani

Population Council

Follow this and additional works at: https://knowledgecommons.popcouncil.org/departments_sbsr-hiv

Part of the Demography, Population, and Ecology Commons, Family, Life Course, and Society Commons, Health Policy Commons, International Public Health Commons, and the Medicine and Health Commons How does access to this work benefit you? Let us know!

\section{Recommended Citation}

Jani, Nrupa. 2013. "HIVCore operations research workshop summary report." Washington, DC: USAID | Project Search: HIVCore. 


\section{(-) USAID Project SEARCH HIVCpre}

\section{HIVCORE OPERATIONS RESEARCHWORKSHOP SUMMARY REPORT}

WASHINGTON, DC, 2 I JULY 2012

\section{AUGUST 2013}

This publication was produced for review by the United States Agency for International Development. It was prepared by Nrupa Jani, HIVCore/Population Council. 



\section{HIVCORE OPERATIONS RESEARCH WORKSHOP SUMMARY REPORT}

\section{WASHINGTON DC 2 I JULY 2012}

NRUPA JANI

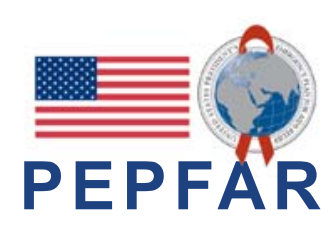




\section{ACKNOWLEDGEMENTS}

The HIVCore team would like to thank all of the workshop participants for their time and sharing their experiences.
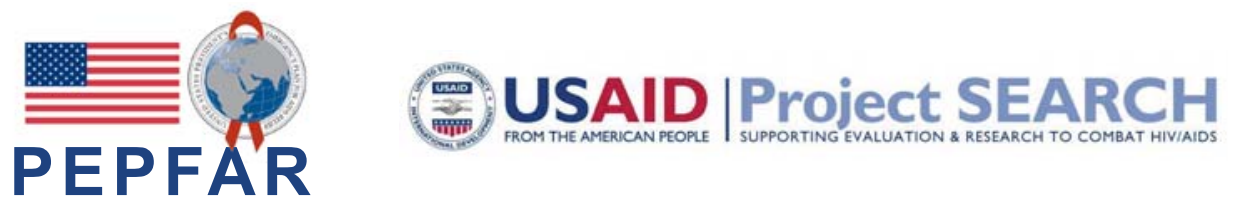

This report was made possible through support provided by the President's Emergency Plan for AIDS Relief and the U.S. Agency for International Development (USAID) via HIVCore, a Task Order funded by USAID under the Project SEARCH indefinite quantity contract (Contract No. AID-OAA-TO-11-00060).

\section{HIVCore improves the efficiency, effectiveness, scale, and quality of HIV treatment, care, and support, and prevention of mother-to-child transmission (PMTCT) programs. The Task Order is led by the Population Council in partnership with the Futures Group, the Elizabeth Glaser Pediatric AIDS Foundation, and the University of Washington.}

Published in August 2013. (C2013. The Population Council Inc.

Suggested citation: Jani, Nrupa. 2013. "HIVCore operations research workshop summary report, Washington, DC, 21 July 2012," HIVCore Final Report. Washington, DC: USAID | Project Search: HIVCore. 


\section{TABLE OF CONTENTS}

\section{ACRONYMS}

INTRODUCTION

WORKSHOP OBJECTIVES $\quad 2$

Implementation challenges and prospective operations research opportunities 2

Using operations research to improve programs: A simple framework 4

$\begin{array}{ll}\text { Country operations research successes } & 6\end{array}$

SUMMARY \& CLOSING REMARKS $\quad 8$

ANNEX I:AGENDA 9

ANNEX 2: HIVCORE PROJECT DIRECTOR PRESENTATION 10

ANNEX 3: LIST OF WORKSHOP PARTICIPANTS 20 


\section{ACRONYMS}

$\begin{array}{ll}\text { AIDS } & \text { acquired immune deficiency syndrome } \\ \text { ANC } & \text { antenatal care } \\ \text { ART } & \text { antiretroviral therapy } \\ \text { ARV } & \text { antiretroviral (drugs) } \\ \text { CD4 } & \text { cluster of differentiation 4 (type of immune cells that help fight infection) } \\ \text { EGPAF } & \text { Elizabeth Glaser Pediatric AIDS Foundation } \\ \text { EID } & \text { early infant diagnosis of HIV } \\ \text { GNP+ } & \text { Global Network of People Living with HIV/AIDS } \\ \text { HTC } & \text { HIV testing and counseling } \\ \text { HIV } & \text { human immunodeficiency virus } \\ \text { IAS } & \text { International AIDS Society } \\ \text { IDU } & \text { injecting drug users } \\ \text { MARPs } & \text { most-at-risk populations } \\ \text { MCH } & \text { maternal and child heath } \\ \text { MSM } & \text { men who have sex with men } \\ \text { OR } & \text { operations research } \\ \text { PCR } & \text { polymerase chain reaction (test for HIV) } \\ \text { PEPFAR } & \text { President's Emergency Plan for AIDS Relief } \\ \text { PHDP } & \text { Positive Health, Dignity and Prevention } \\ \text { PMTCT } & \text { prevention of mother-to-child transmission of HIV } \\ \text { PrEP } & \text { pre-exposure prophylaxis } \\ \text { SEARCH } & \text { Supporting Evaluation and Research to Combat HIV/AIDS } \\ \text { TB } & \text { tuberculosis } \\ \text { UNAIDS } & \text { Joint United Nations Programme on HIV/AIDS } \\ \text { USAID } & \text { United States Agency for International Development } \\ \text { UW } & \text { University of Washington } \\ \text { WHO } & \text { World Health Organization } \\ & \end{array}$




\section{INTRODUCTION}

Over the past decade, unprecedented progress has been made in the scale-up of HIV treatment, care and support, and prevention of mother-to-child transmission of HIV (PMTCT) programs. Yet substantial coverage gaps remain, many patients are not receiving the recommended standard of care, and resources are increasingly constrained. Targeted operations research (OR) and program evaluation can play a significant role in ensuring efficient and effective service delivery, scaling up to reach more clients and on a broader geographical scope, enhancing quality of care, and improving the health status and health systems in developing country settings. With funding from the U.S. Agency for International Development (USAID), the Population Council in partnership with the Futures Group, the Elizabeth Glaser Pediatric AIDS Foundation (EGPAF), and the University of Washington (UW) are responding to these critical service delivery issues through HIVCore.

HIVCore is a three year Task Order funded by USAID under the project Supporting Evaluation and Research to Combat HIV/AIDS (SEARCH) indefinite quantity contract (Contract No. AID-OAATO-11-00060). It can accept field support from USAID Missions for HIV and AIDS treatment, care and support, and PMTCT operations research and basic program evaluation activities. The Task Order is led by the Population Council in partnership with the above partners.

HIVCore improves the efficiency, effectiveness, scale, and quality of HIV and AIDS treatment, care and support, and PMTCT programs by:

1. Conducting OR and evaluations in order to expand the evidence base of effective service delivery approaches at the global, country, and program levels;

2. Promoting utilization of research and program evaluation results and other strategic information to enhance decision making; and

3. Building local capacity to identify research questions, conduct OR and focused evaluations, and use research findings.

In order to obtain input from program managers as well as share its research agenda, HIVCore convened an OR workshop for selected national-level HIV program managers and researchers attending the International AIDS Society (IAS) conference in July 2012 in Washington, DC. 


\section{WORKSHOP OBJECTIVES}

1. Identify key service delivery implementation challenges in countries where workshop participants are working and prospective OR opportunities to address them.

2. Describe OR/evaluation activities currently taking place in these countries, including successes, challenges, and gaps.

3. Share promising practices in improving program delivery to extract lessons learned.

The workshop was attended by a total of 24 participants from service delivery organizations, research institutions, government, and donors representing six countries. This report summarizes the proceedings of the workshop. These discussions are an important contribution to the refinement of HIVCore's OR framework and agenda. It is also hoped that, as a result of this workshop, participants will be better able to apply OR principles in their respective settings as a simple, problem-solving approach to program improvement. The report concludes with a way forward which encourages using OR and program evaluation in a step-by-step approach to identify and solve program challenges while documenting and disseminating findings.

\section{IMPLEMENTATION CHALLENGES AND PROSPECTIVE OPERATIONS RESEARCH OPPORTUNITIES}

Participants identified an array of challenges in the areas of HIV treatment, PMTCT, and care and support that could be addressed using OR.

\section{Adherence and retention in HIV treatment}

The success or failure of HIV treatment programs depends on patient maintenance on treatment and adherence to the prescribed regimens. A critical point for antiretroviral therapy (ART) retention appears to be in the initial period following treatment initiation. Experience from a variety of programs not limited to HIV suggests that the highest rates of discontinuation tend to be in the early period after initiation and that attrition rates among patients who make it past this period are much lower. Rates and factors affecting retention and adherence are thus critical to examine at different time points after initiation, for various populations and in various settings.

One particularly vulnerable group for poor ART retention and adherence is adolescents. Young men and women who were infected with HIV, whether perinatally or in adolescence, experience unique sexual and reproductive health needs compared to other age groups, which may affect their ART retention and adherence.

An additional OR need within adult care and treatment identified by workshop participants was the examination of task shifting as a strategy to increase access to HIV treatment. 


\section{PMTCT}

Providing ART to HIV-positive pregnant and post-partum women is a highly effective strategy to prevent transmission to their children during pregnancy, delivery, and breastfeeding. HIV-positive pregnant and post-partum women may also be in need of treatment for their own health. Recent World Health Organization (WHO) guidelines call for a minimum of short-term antiretroviral (ARV) prophylaxis for PMTCT during pregnancy, delivery, and breastfeeding for those not in need of treatment (Option A), and lifelong ART for HIV-positive women in need of treatment for their own health (Option B). Effectively providing Option B requires prompt CD4 testing of HIV-positive pregnant women to determine eligibility for treatment; however, associated operational challenges in the provision of CD4 testing remain to be documented.

Many countries are moving to Option B+, which provides lifetime ART to all HIV-positive pregnant women irrespective of their clinical status. In theory, this should make it easier to initiate ART, since all HIV-positive women would receive the same treatment. However, currently there are few operational data on Option B+.

During pregnancy and in the post-partum period, ART may be provided in the antenatal/maternal child health $(\mathrm{MCH})$ setting or in treatment (ART) clinics. Eventually, however, pregnant and post-partum women complete the $\mathrm{MCH}$ portion of their care. A particular challenge is deciding when and how to transition women out of $\mathrm{MCH}$ clinics to ART clinics. What can be done to optimize ART uptake and adherence by these women and how can countries effectively integrate PMTCT and long-term ART care? Access to and analysis of longitudinal data would provide some answers to these questions. It is thus important that when service transitions take place, as in the case from PMTCT to ART, clinics ensure that patient records are efficiently transferred or linked to enable tracking of mothers.

Another program priority is to understand factors associated with infant testing for HIV and treatment initiation and adherence for infants who become infected. Early infant diagnosis (EID) of HIV infection requires specialized testing using polymerase chain reaction (PCR). For a variety of reasons, countries have been slow to scale up PCR testing of HIV-exposed infants. This not only hampers monitoring clinical outcomes but also makes it difficult to evaluate PMTCT program success in reducing infant infections. At the moment there are only small-scale studies measuring HIV infection in infants known to have been exposed to HIV perinatally. These studies often make special efforts to follow up mother-baby pairs and test infants for HIV, usually at six weeks post delivery. However, to gauge program effectiveness it is important to monitor HIV prevalence among infants more broadly and for a longer period of follow-up, for different infant feeding options, and under different treatment regimens. Surveillance of HIV-exposed infants attending routine immunization clinics is a promising approach for measuring PMTCT program effectiveness, as vaccination coverage is generally high at six weeks of age and these infants are reasonably representative of the general population. OR on the implementation of this approach is needed to develop guidelines for deciding where and how to roll out such surveillance systems.

Additional OR needs within PMTCT programming identified by workshop participants include improving timing of CD4 testing and receiving results, establishing HIV surveillance among HIVexposed infants throughout the period of breastfeeding, stronger program evaluations across Option A, $\mathrm{B}$, and $\mathrm{B}+$ settings, adherence to infant $\mathrm{ARV}$ prophylaxis, antenatal care (ANC) demand generation, improving the quality of HIV testing and treatment data among ANC clients, and testing the use of mobile technology in the follow-up of PMTCT clients and their infants. 


\section{Care and support and linkages to treatment}

Once an individual has been diagnosed as HIV-positive, it is important that he or she enrolls for care as soon as possible, in order to determine eligibility for treatment, begin treatment if eligible, and receive other care and support. Yet there remains a paucity of data on the continuum from HIV testing and counseling (HTC) to enrollment in and provision of pre-ART care to eventual initiation of treatment.

Other care and support questions also remain unanswered. Are there successful and cost effective models of Positive Health, Dignity, and Prevention (PHDP) ${ }^{1}$ in the African setting? If so, which countries have implemented the full continuum of care defined under PHDP by UNAIDS and the Global Network of People Living with HIV (GNP+)? Related to this is the need to study interventions for reducing HIV transmission within discordant couples, such as pre-exposure prophylaxis (PrEP). It is also important to recognize different models of care and support for most at-risk populations (MARPs), including injecting drug users (IDU) and mobile populations such as truck drivers and sex workers.

Additional OR needs within linkages to care, support, and treatment identified by workshop participants include exploring the implementation of the PEPFAR package and definition of care and support, and strategies to increase ART enrollment of tuberculosis (TB) co-infected patients.

A number of studies planned for implementation during the second year of HIVCore have been designed to respond to the OR needs identified by various workshop participants. To add to the growing body of research in HIV treatment, HIVCore is planning an analysis of retention and adherence in ART treatment programs serving adolescents in Uganda, as well as a review of selected task-shifting programs in the same country. The team is also undertaking secondary analysis of PMTCT program data from several countries to examine retention in the PMTCT cascade. Per the request of the USAID mission, HIVCore is designing a study to analyze the PMTCT cascade in Cote d'Ivoire in a two-phase national level study. Several studies are also planned to examine potential ways of improving maternal adherence to ART. One prospective study is tasked with examining linkage from HTC to enrollment in care and treatment. Another study proposes to use secondary analysis of patient clinical records to identify gaps and delays in assessment for eligibility to treatment and also explore the role of pre-ART care in the ultimate retention and adherence on treatment.

\section{USING OPERATIONS RESEARCHTO IMPROVE PROGRAMS: A SIMPLE FRAMEWORK}

Program managers are always looking for ways to improve their programs. The workshop offered a simple framework for using OR as a problem-solving tool for program improvement that involves asking three sets of questions:

1. Is there a problem and if so, how big is the problem? Are our data valid to even tell us if there is a problem?

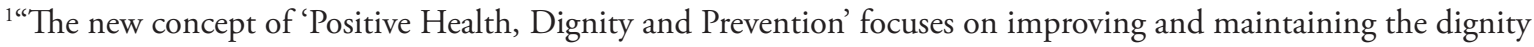
of the person living with HIV, which has a positive impact on the person's health, and which, in turn, creates and enabling environment that will reduce the likelihood of new HIV infections." http://www.gnpplus.net/en/ programmes/positive-health-dignity-and-prevention/positive-health-dignity-and-prevention/1659-media-statementpositive-health-dignity-and-prevention
} 
2. Where is the problem? Is it across the board or more in some clinics than in other clinics? Are there differences that can be identified by systematically comparing high performing sites and low performing sites at each step of the process? (If the problem is common, then the solution would require program or national-level attention, while if the problem varies from clinic to clinic, this would require a clinic-level intervention.)

\section{What are the steps to achieving the desired outcome (stepwise analysis)?}

Once these questions have been answered, programs can propose a solution at the appropriate step in the process, implement it in the low performers, and measure its impact early on. If it works, programs can expand it; if it doesn't, they can move on to something else.

In brief, not all problems need sophisticated research solutions, as evidenced by the following two country examples.

\section{Mozambique}

A PMTCT program in Mozambique identified frequent delays for women testing HIV-positive and being tested for CD4. This was often due to physicians being slow to order the test. Since all HIV-positive women were supposed to get a CD4 test, the program tried a simple solution: rather than reminding the clinicians, the responsibility for ordering the test was delegated to the receptionist. This resulted in a dramatic increase in the percentage of women who were tested for CD4, received their test results, and discussed them with the doctor.

\section{Cote d'Ivoire}

The Cote d'Ivoire PMTCT program follows opt-out HIV testing. All women not previously known to be HIV-positive are supposed to be tested for HIV at their first ANC visit for that pregnancy. Reported testing rates are very high.

As part of a feasibility assessment for a PMTCT prospective study, the HIVCore team visited immunization clinics close to ANC services and asked to see women's mother-baby cards. These cards capture mothers' HIV test results as well as services received. A quick look at 14 cards from an ANC clinic that had previously reported a 95 percent test rate revealed that only about half of the women had actually been tested. A closer look showed that most of the women who had not been tested for HIV had visited a different clinic site, which did not offer HIV testing, for their first ANC visit; this allowed them to acquire a mother-baby health card without having to be tested for HIV. Thus the 95 percent testing rate only applied to a subset of women using the facility. When all women are included in the denominator, the percent tested is much lower.

This finding was unexpected and investigating the accuracy of the reported percent of ANC women tested was not part of the original study design. The researchers are now planning to collect a larger and more representative sample of mother-baby health cards. If the findings hold-that substantial proportions of women are making their first ANC visit to sites that do not follow the opt-out HIV testing strategy and are thereby avoiding being tested for HIV - they would indicate that in spite of the reported and impressive 95 percent national test rate, there is a real problem that needs to be addressed. 


\section{From program improvement to OR}

Operations research is an extension of routine problem solving, as demonstrated by the simple yet effective programmatic evaluation and adaptation in Mozambique in the example above. Many problems and solutions can be identified by analyzing routinely-collected service data without additional data collection.

The OR approach encourages program staff to use their own data to identify problems and devise solutions for improving the efficiency and effectiveness of their programs. This type of program analysis does not require formal research processes or approvals. USAID and PEPFAR both promote systematic review and documentation of program data and encourage program implementers to exercise rigor in their analysis and presentation of program data to share valuable findings.

Simple program problem solving and quality improvement by identifying problem areas and testing solutions while measuring the effect becomes research when taken to scale. When the need for a more systematic and formalized program review arises, program managers may seek collaboration with researchers to refine program questions that can be answered through systematic OR and to develop study protocols.

A general challenge cited across all aspects of HIV service delivery is that service providers are overwhelmed by additional data collection requirements imposed by HIV programs, and desire a more streamlined approach to data collection. HIVCore endeavors to develop data capture methodologies to extract relevant information from data collected using existing clinical forms. If such a methodology is deemed useful, the hope is that the clinic managers will then adopt it to their setting to analyze the data that are already being collected and generate evidence for program improvement.

\section{COUNTRY OPERATIONS RESEARCH SUCCESSES}

Workshop participants shared their experience of how they have used OR in their respective settings to improve service delivery as well as promising approaches that could be tested in OR. The following four country examples present promising approaches to common OR challenges in HIV counseling, testing, PMTCT, and treatment settings.

\section{Zimbabwe}

Engaging local community leaders in Zimbabwe and improving access to CD4 testing has led to increased treatment retention rates and demand for services. A pilot program is using peer facilitators--women who have received ANC care as per the national guidelines--to encourage pregnant women to seek ANC services. These peer facilitators have proven successful in community mobilizing for PMTCT, retention in care, and postnatal HIV testing. Another pilot test is using point of care technology to improve CD4 testing for women seen at $\mathrm{MCH}$ clinics and postnatally.

\section{Lesotho}

Program reviews in Lesotho have highlighted a number of promising operational solutions. For example, tuberculosis active case finding among women receiving PMTCT services has led to higher treatment rates. Research on HIV testing rates among women in Lesotho who return to ANC visits demonstrated 
that women who knew their HIV status (negative or positive) had higher attendance rates than those who did not know their status. A program review on the use of $3 \mathrm{G}$ mobile technology to distribute DNA PCR results found a reduced turnaround time of 50 percent. Additionally, a task shifting study showed that use of nurse midwives improved EID and initiation of ART for children in the absence of pediatricians.

\section{Nigeria}

In Nigeria program data are showing a number of promising community-level interventions to improve program effectiveness that could be tested through OR. A task shifting strategy involving training men who have sex with men (MSM) in HIV counseling and testing to test and link their peers to ART treatment centers resulted in an increase in the number of high-risk men who know their status and also led to increased, selective testing of MSM and friends of known HIV-positive persons. Similarly, community mobilization and engagement structures have also been used to forge linkages in testing and treatment. In northern Nigeria, healthy mothers clubs have been used to enhance HIV testing, prevention, care, and treatment. Alternative, non-clinic-based approaches are also being used to provide linkages to these women, as many have revealed the preference to be tested for HIV in community settings that ensure privacy of their status.

\section{Zambia}

The NGO "mothers2mothers" in Zambia has formed support group forums to educate women to get tested for HIV. This community engagement has encouraged men to also get tested along with their partners, which has resulted in higher PMTCT coverage rates. These are interventions that could benefit from OR to generate evidence of their effectiveness. 


\section{SUMMARY \& CLOSING REMARKS}

Several OR challenges and potential solutions were identified throughout the course of this workshop. While some are harder to evaluate than others, collaboration between program managers and researchers can result in OR study designs that can provide evidence on program solutions. It is interesting to note that while times have changed, many of the same programmatic challenges that were identified early in the PEPFAR program are still being discussed today. Indeed, these are not problems that can be resolved easily or quickly and instead must be approached one step at a time, documenting and disseminating best practices as they occur.

The current atmosphere of limited resources should not discourage program managers from conducting simple, effective, quality OR. It is important to keep in mind that OR studies do not always necessitate a counterfactual control group or large sample sizes. Often routine data readily available to programs can be analyzed and used to strengthen service delivery processes. Operations research studies are also beginning to examine how lessons from HIV treatment, prevention, and care and support programs can be used in fostering an entire health systems strengthening approach. This versatility is something to consider as we continue to innovate various ways to strengthen service delivery.

As HIVCore enters the second year of its mandate we continue to refine our conceptualization of OR. There are many new promising practices piloted in OR. Our problem-solving framework will continue to integrate key issues and research studies identified during this workshop. It is our hope that discussion of these priority issues and designing solutions to them will continue at the country, regional, and international levels and that we will keep each other appraised of emerging evidence as well as resulting successes and challenges. 


\section{ANNEX I:AGENDA}

\section{HIVCORE OPERATIONS RESEARCH WORKSHOP JULY 2 I, 20 I 2

\author{
9:00am- I:00pm
} \\ Embassy Suites Washington DC,Tenleytown Ballroom}

\begin{tabular}{|c|c|c|}
\hline Time & Sessions & Session Lead \\
\hline \multirow[t]{2}{*}{ 9:00-9:30am } & Registration, Breakfast \& Networking & Nrupa Jani \& \\
\hline & & Sherry Hutchinson \\
\hline \multirow[t]{4}{*}{ 9:30-10:00am } & Introductions & Karen Foreit \\
\hline & Welcome \& workshop objectives & Naomi Rutenberg \\
\hline & Introduction to HIVCore as a USAID mechanism & Sarah Sandison \\
\hline & HIVCore activities & Sam Kalibala \\
\hline \multirow[t]{5}{*}{ |0:00- | I:00am } & Setting the stage for small group discussion & Stephen Gloyd \\
\hline & Discussion questions & \\
\hline & $\begin{array}{l}\text { I. What are the key policy or implementation } \\
\text { challenges? }\end{array}$ & \\
\hline & $\begin{array}{l}\text { 2. What program evaluation or research activities are } \\
\text { taking place to address these issues? }\end{array}$ & \\
\hline & $\begin{array}{l}\text { 3. Are there promising practices in improving program } \\
\text { delivery from which we would like to extract lessons? }\end{array}$ & \\
\hline \multirow[t]{2}{*}{$11: 00-12: 00 p m$} & Report back from small group discussions & Godfrey Woelk \\
\hline & General discussion in large group & \\
\hline $12: 00-12: 10 \mathrm{pm}$ & Wrap-Up \& Way Forward & Naomi Rutenberg \\
\hline I2:10-I:00pm & Boxed Lunches \& Networking & \\
\hline
\end{tabular}




\section{ANNEX 2: HIVCORE PROJECT DIRECTOR PRESENTATION}

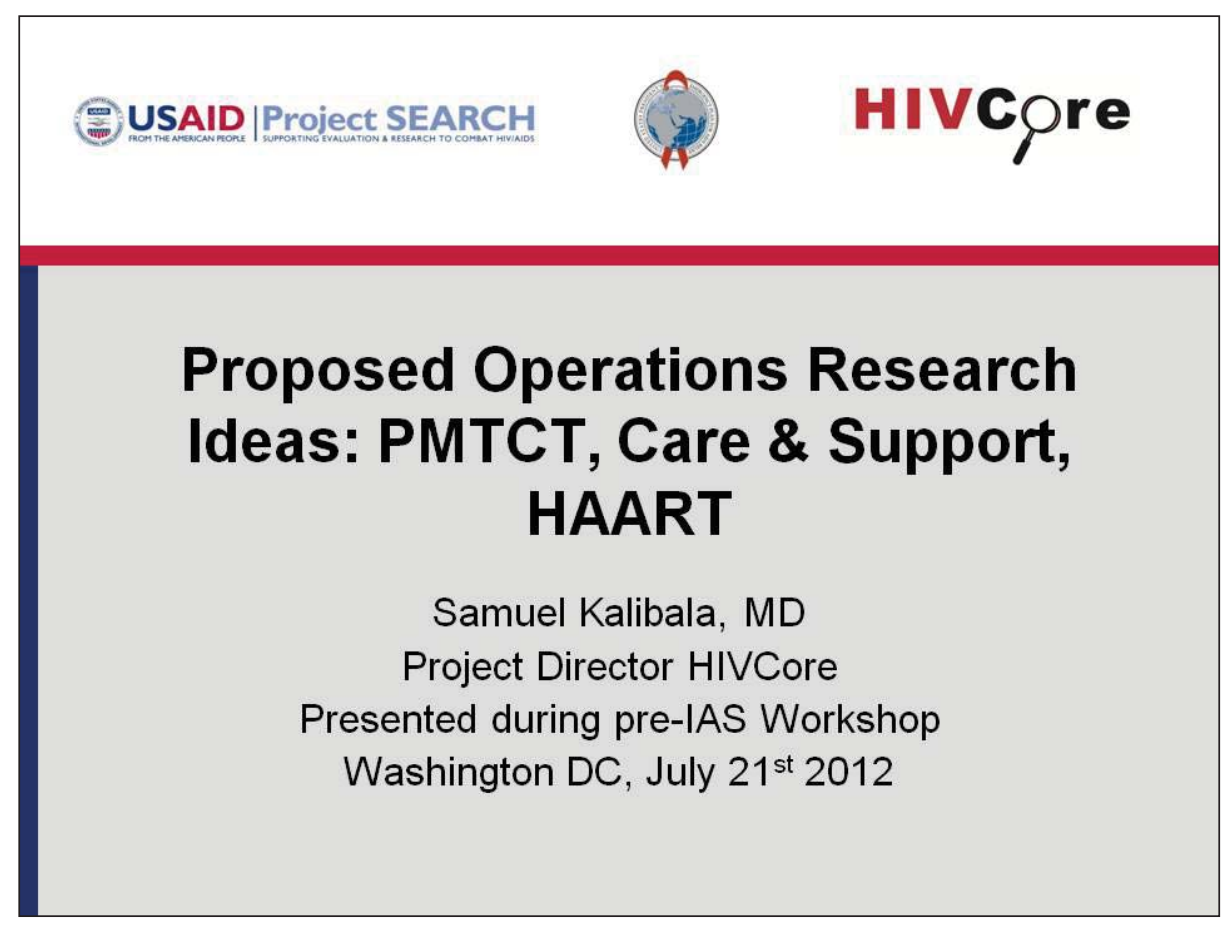


Task Order Goal

Measurably improve PEPFAR II treatment, care and support, and PMTCT programs

\begin{tabular}{|l|l|}
\hline TSAID | Project SEARCH \\
\hline The HIVCore Consortium \\
\hline Partner & Technical Strength \\
\hline $\begin{array}{l}\text { Population Council } \\
\text { (prime contractor) }\end{array}$ & $\begin{array}{l}\text { OR and evaluation of HIV programs, OR } \\
\text { capacity building, management of large } \\
\text { USAID awards }\end{array}$ \\
\hline Futures Group & $\begin{array}{l}\text { Strategic information, data for decision } \\
\text { making, dissemination, information use } \\
\text { for programs and data triangulation }\end{array}$ \\
EGPAF & $\begin{array}{l}\text { PMTCT and pediatric HIV service delivery } \\
\text { and OR }\end{array}$ \\
University of Washington & $\begin{array}{l}\text { Treatment, care and support, and PMTCT } \\
\text { service delivery and OR }\end{array}$ \\
\hline
\end{tabular}




\section{Our Strategies}

1. Conducting operations research and evaluation in order to expand the evidence base of effective service delivery approaches at the global, country, and program levels;

2. Promoting utilization of research and program evaluation results and other strategic information to enhance decision making; and

3. Building local capacity to identify research questions, conduct operations research and focused evaluations, and use research findings.

Status of Study Proposals June 2012 (N=16)

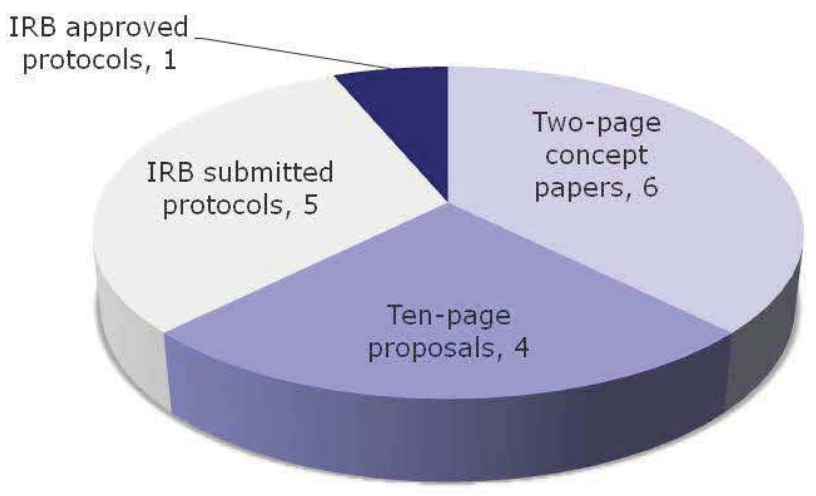


Purpose

Outline HIVCore's current ideas for Operations Research and obtain your input and feedback

\section{HIVCpre}
A. OPERATIONS RESEARCH IDEAS ON HAART FOR ADULTS \& ADOLESCENTS 


\section{Secondary Data Analysis Studies on ART}

\begin{tabular}{|c|c|c|}
\hline $\begin{array}{l}\text { Program } \\
\text { issue }\end{array}$ & $\begin{array}{l}\text { Proposed } \\
\text { methodology }\end{array}$ & Proposed indicators \\
\hline $\begin{array}{l}\text { HAART } \\
\text { adherence } \\
\text { among } \\
\text { adolescents }\end{array}$ & $\begin{array}{l}\text { 1. Retrospective } \\
\text { data analysis of } \\
\text { clinical data } \\
\text { 2. Review of } \\
\text { counseling logs }\end{array}$ & $\begin{array}{l}\text { 1. HTC-HAART cascade } \\
\text { 2. Retention and adherence among } \\
\text { adolescents by demographics } \\
\text { 3. Socio-behavioral factors affecting } \\
\text { adherence and retention }\end{array}$ \\
\hline $\begin{array}{l}\text { National } \\
\text { retention } \\
\text { and } \\
\text { treatment } \\
\text { outcomes }\end{array}$ & $\begin{array}{l}\text { 1. Retrospective } \\
\text { data analysis of } \\
\text { merged } \\
\text { national clinical } \\
\text { data bases } \\
\text { including cohort } \\
\text { analysis }\end{array}$ & $\begin{array}{l}\text { Longitudinal changes in selected national } \\
\text { level indicators, e.g.: } \\
\text { 1. Patients initiating treatment from period } X \\
\text { to } Y \\
\text { 2. Retention after } 3,6,9,12 \text { months } \\
\text { 3. Percent in care who received cotrimoxazole } \\
\text { 4. Percent in care who received TB screening }\end{array}$ \\
\hline
\end{tabular}

B. OPERATIONS RESEARCH

IDEAS ON HTC, CARE \& SUPPORT 


\section{Secondary Data Analysis Studies on HTC, C\&S}

\begin{tabular}{|c|c|c|}
\hline Program issue & Proposed methodology & Proposed indicators \\
\hline $\begin{array}{l}\text { Operational } \\
\text { definition of HIV } \\
\text { care and support }\end{array}$ & $\begin{array}{l}\text { 1. Develop tool for } \\
\text { assessment of current } \\
\text { practices and gaps in care } \\
\text { \& support } \\
\text { 2. Pilot test the assessment } \\
\text { tool in at least three } \\
\text { countries with different } \\
\text { characteristics of epidemic }\end{array}$ & $\begin{array}{l}\text { 1. Draft assessment tool for } \\
\text { practices/gaps of care \& } \\
\text { support } \\
\text { 2. Tested assessment tool for } \\
\text { practices/gaps of care \& } \\
\text { support for use by national } \\
\text { programs }\end{array}$ \\
\hline $\begin{array}{l}\text { Gaps in HIV policies } \\
\text { and programs for } \\
\text { people with } \\
\text { disabilities }\end{array}$ & 1. Conduct situation analysis & $\begin{array}{l}\text { 1. Mapping of gaps in HIV } \\
\text { policies and programs for } \\
\text { people with disabilities and } \\
\text { recommendations for } \\
\text { addressing gaps }\end{array}$ \\
\hline
\end{tabular}

USAID $\mid$ Project SEARCH

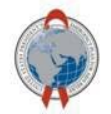

HIVCpre

\section{Primary Data Collection Studies on HTC, C\&S}

\begin{tabular}{|c|c|c|}
\hline Program issue & Proposed methodology & Proposed indicators \\
\hline $\begin{array}{l}\text { Contextual } \\
\text { barriers to HTC } \\
\text { linkage to care }\end{array}$ & $\begin{array}{l}\text { 1. Current statistics and } \\
\text { mappings from HTC to } \\
\text { care sites to identify } \\
\text { bottlenecks } \\
\text { 2. Participatory assessment } \\
\text { of contextual and health } \\
\text { systems barriers and } \\
\text { develop interventions } \\
\text { 3. Baseline and monitoring } \\
\text { of statistics }\end{array}$ & $\begin{array}{l}\text { 1. HTC to Care } \\
\text { Cascade and } \\
\text { bottlenecks } \\
\text { 2. Barriers and } \\
\text { solutions } \\
\text { 3. Improved HTC to } \\
\text { Care Cascade }\end{array}$ \\
\hline
\end{tabular}




\section{Primary Data Collection Studies on ART}

\section{Program issue \\ methodology}

Task shifting in ART

care: what are the models, what is the retention levels, what does it cost?
1. Description of models

2. Time motion observation

3. Exit interviews

4. Provider surveys

5. Cohort analysis

6. Cost analysis
Proposed indicators

1. Who, what, where of task shifting?

2. Client satisfaction

3. Provider satisfaction

4. Retention

5. Cost per client per year

\section{Primary Data Collection Studies on HTC, C\&S (cont'd)}

\section{Program issue}

Psychosocial needs of vulnerable children and risk of HIV

TB screening and diagnosis among clients on ART
Proposed methodology

1. Assessment of psychological disorders and HIV vulnerability

2. Screening Tool Adaptation

3. Test psychosocial support Interventions

1. Enhance screening through clinician reminders placed in clinical files

2. Enhance diagnosis by moving TB microscopy stain into HIV lab

\section{Proposed indicators}

1. Prevalence of psychological disorders and HIV risk behaviors

2. Impact of intervention on psychological disorders and ultimately HIV risk

1. Increased \# screened and \# given IPT

2. Increased\# with sputum results 


\section{OPERATIONS RESEARCH IDEAS ON PMTCT AND PEDIATRIC AIDS}

\begin{tabular}{|c|c|c|}
\hline \multicolumn{3}{|c|}{ (3) USAID | Project SEARCH } \\
\hline \multicolumn{3}{|c|}{ Secondary Data Analysis Studies on PMTCT } \\
\hline $\begin{array}{l}\text { Program } \\
\text { issue }\end{array}$ & $\begin{array}{l}\text { Proposed } \\
\text { methodology }\end{array}$ & Proposed indicators \\
\hline $\begin{array}{l}\text { What are } \\
\text { retention rates } \\
\text { in Option A vs. } \\
\text { Option B } \\
\text { countries? }\end{array}$ & $\begin{array}{l}\text { 1. Retrospective } \\
\text { cohort analysis of } \\
\text { demographic and } \\
\text { clinical exposures }\end{array}$ & $\begin{array}{l}\text { 1. Retention at different time points } \\
\text { 2. Retention across facilities } \\
\text { 3. Retention in active v. passive follow-up } \\
\text { 4. Retention by demographic characteristics }\end{array}$ \\
\hline $\begin{array}{l}\text { What is the } \\
\text { "CD4 to } \\
\text { HAART" } \\
\text { Cascade in } \\
\text { PMTCT? }\end{array}$ & $\begin{array}{l}\text { 1. Retrospective } \\
\text { cohort analysis of } \\
\text { Option A and } \\
\text { Option B clients }\end{array}$ & $\begin{array}{l}\text { 1. Proportion of HIV+ ANC attendees tested for } \\
\text { CD4 } \\
\text { 2. Proportion of HIV+ ANC attendees tested for } \\
\text { CD4 who received CD4 results } \\
\text { 3. Proportion of HAART eligible HIV+ ANC } \\
\text { attendees who initiate HAART } \\
\text { 4. Proportion of HIV+ ANC attendees who are } \\
\text { retained on HAART or appropriate ARV } \\
\text { prophylaxis } \\
\text { 5. Explore factors affecting cascade }\end{array}$ \\
\hline
\end{tabular}




\section{Primary Data Collection Studies on PMTCT}

\begin{tabular}{|c|c|c|}
\hline Program issue & $\begin{array}{c}\text { Proposed } \\
\text { methodology }\end{array}$ & Proposed indicators \\
\hline $\begin{array}{l}\text { Can intensive MCH } \\
\text { counseling improve } \\
\text { operational efficacy of the } \\
\text { WHO Option B approach? }\end{array}$ & $\begin{array}{l}\text { 1. Intensive patient- } \\
\text { centered adherence } \\
\text { counseling of HIV+ } \\
\text { mothers who initiate } \\
\text { HAART }\end{array}$ & $\begin{array}{l}\text { 1. Proportion of HIV+ pregnant women tested } \\
\text { who successfully initiate appropriate ARVs } \\
\text { within } X \text { months of HIV testing. } \\
\text { 2. ARV adherence rate at } \underline{X} \text { days after } \\
\text { HAART initiation and at } 6 \text { months post } \\
\text { partum. } \\
\text { 3. Newborn HIV status as per PCR test at } \\
\text { birth and again at } 6 \text { months after birth. }\end{array}$ \\
\hline $\begin{array}{l}\text { What follow-up mechanisms } \\
\text { can improve adherence to } \\
\text { HAART in PMTCT } \\
\text { programs? }\end{array}$ & $\begin{array}{l}\text { 1. Phone counseling } \\
\text { intervention delivered } \\
\text { by nurses } \\
\text { 2. Face to face } \\
\text { counseling delivered } \\
\text { by CHWs }\end{array}$ & $\begin{array}{l}\text { 1. Levels of acceptability, feasibility and cost } \\
\text { of implementing either phone or face to } \\
\text { face counseling } \\
\text { 2. Factors associated with non-adherence } \\
\text { 3. Initiation rates of women on HAART } \\
\text { 4. Retention rates of women on HAART }\end{array}$ \\
\hline $\begin{array}{l}\text { What is the MTCT rate at } \\
\text { national level? } \\
\text { How can a countrymonitor } \\
\text { progress to eMTCT? }\end{array}$ & $\begin{array}{l}\text { 1. EID surveillance at six } \\
\text { week clinics } \\
\text { 2. Mother-baby pair } \\
\text { cohorts }\end{array}$ & $\begin{array}{l}\text { 1. HIV incidence in HIV exposed infants } \\
\text { 2. HIV free survival among HIV exposed } \\
\text { infants by infant feeding type }\end{array}$ \\
\hline
\end{tabular}

\section{USAID |Project SEARCH}

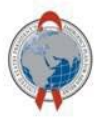

\section{HIvcpre}

\section{Pediatric Testing and Treatment}

\begin{tabular}{|c|c|c|}
\hline Program issue & Proposed methodology & Proposed indicators \\
\hline $\begin{array}{l}\text { How can we } \\
\text { expand coverage } \\
\text { of HIV testing and } \\
\text { ART for infants of } \\
\text { HIV+ mothers? }\end{array}$ & $\begin{array}{l}\text { 1. Add HIV testing for infants to } \\
\text { existing entry points to } \\
\text { services, such as enhanced } \\
\text { postpartum service, } \\
\text { vaccination, and IMCI } \\
\text { 2. Use mobile phones for } \\
\text { referring and and tracking } \\
\text { infants } \\
\text { 3. Email transmission of PCR } \\
\text { results from reference lab to } \\
\text { facility }\end{array}$ & $\begin{array}{l}\text { 1. Number of HIV exposed } \\
\text { infants tested for HIV } \\
\text { 2. Number of HIV exposed } \\
\text { infants started on } \\
\text { septrin/bactrim } \\
\text { prophylaxis } \\
\text { 3. Number of HIV+ infants } \\
\text { started on ART }\end{array}$ \\
\hline
\end{tabular}




USAID Project SEARCH
QUESTIONS?
THANK YOU




\section{ANNEX 3: LIST OF WORKSHOP PARTICIPANTS}

\begin{tabular}{|ll|}
\hline Name & Organization/Affiliation \\
\hline Sylvia Adebajo & Population Council Nigeria \\
Victor Aduayi & Obafemi Awolowo University, Nigeria \\
Ugochukwu Amanyeiwe & USAID \\
Karen Foreit & Futures Group \\
Robert Farias & Cnapsis Inc \\
Steve Gloyd & University of Washington \\
Sherry Hutchinson & Population Council \\
Nrupa Jani & Population Council \\
Sam Kalibala & Population Council \\
Andrew Karlyn & Population Council \\
Milly Kayongo & USAID \\
Benny Kottiri & USAID \\
Kwashie Kudiabor & EGPAF Swaziland \\
Marcia Monjane & USAID Mozambique \\
Auxilia Muchedzi & EGPAF Zimbabwe \\
Owen Mugurungi & National Aids Control Program, Zimbabwe \\
Nicolas Muraguri & UNAIDS \\
Glenn Post & USAID \\
Naomi Rutenberg & Population Council \\
Sarah Sandison & USAID \\
Appolinaire Tiam & EGPAF Lesotho \\
Waimar Tun & Population Council \\
Deborah Weiss & Population Council \\
Godfrey Woelk & EGPAF \\
\hline
\end{tabular}



U.S. Agency for International Development I 300 Pennsylvania Avenue, NW

Washington, DC 20523

Tel: (202) 7I2-0000

Fax: (202) 216-3524

www.usaid.gov 